Олгица Спасојевић

ОШ „Петар Лековић“, Пожега
УДК 371.3:811.163.41]:004

доИ https://doi.org/10.18485/

melissa.2016.15.2.ch11

\title{
УЛОГА НАСТАВЕ СРПСКОГ ЈЕЗИКА У РАЗВОЈУ ДИГИТАЛНЕ ПИСМЕНОСТИ
}

\section{Сажетак}

Развој елементарне писмености у 21. веку неодвојив је од дигиталне писмености. Иако се на развоју дигиталне писмености не инсистира у Наставним плановима и програмима за српски језик, он се у пракси подразумева.

У раду је приказано како се различитим наставним активностима организованим кроз употребу технологије постиже развијање дигиталне писмености, паралелно са остваривањем циљева наставе српског језика.

На примерима из праксе показују се могућности које пружа Мудл платформа за организовање различитих наставних активности којима се постижу: унапређење квалитета писаних задатака, примена кооперативног оцењивања, прилагођавање наставних активности индивидуалним потребама ученика, истраживачки рад, подстицање критичког мишљења, унапређење појединих наставних садржаја као што су лексикологија и правопис.

Употреба различитих веб-алата пружа ученицима могућност за комуникацију, сарадњу и креирање дигиталних и мултимедијалних садржаја. Ученици морају схватити да креирање дигиталних садржаја мора пратити и брига о језичкој и правописној норми. Такође, неопходно је непрестано их подсећати на одговорну употребу технологије и поштовање ауторских права.

Коришћењем блога у настави и ваннаставним активностима подстиче се развој креативности, критичког мишљења и дигиталних вештина које престављају основу дигиталне писмености.

Дигиталну писменост могуће је развијати и кроз пројектно оријентисану наставу. Примери интернационалних Етвининг пројеката показују како је могуће интегрисати међународну сарадњу у наставу српског језика.

Кључне речи: дигитална писменост, настава, српски језик

\section{Увод}

Убрзани развој дигиталних технологија утицао је на све области живота и друштва. У потпуности је променио начин живота, рада, 
комуникације међу људима. Самим тим, поставио је и пред систем образовања бројне изазове. Већ неко време постављају се питања како да се образовни систем, који је у највећој мери традиционалан и споро се мења, прилагоди вртоглавим променама које се дешавају у другим областима.

Данашњи ученици од самог рођења окружени су дигиталним технологијама. Истраживања показују да преко 90\% ученика основних школа користи рачунар, а преко $80 \%$ свакодневно користи интернет (Попадић и Кузмановић 7 - 8). Иако их користе од најранијег узраста, пракса показује да их ретко употребљавају у образовне сврхе и на креативан и безбедан начин. Зато је неопходно што раније почети са укључивањем савремених технологија у наставу и подстицати код ученика развој компетенција важних за живот у технолошком окружењу.

Развој технологије постепено мења приступ многим наставним предметима, а пред наставу српског језика поставља посебне изазове. Појам писмености, који је до средине 20. века подразумевао способност читања и писања, добио је нову димензију. Данас се у литератури помиње више врста писмености, при чему се користе различити термини и поделе. Оне које су директно везане за развој нових технологија јесу медијска, информатичка и дигитална писменост (Јурић).

Дефиниције дигиталне писмености су различите и бројне. Највише цитирана је она према којој је способност проналажења, анализе, одабира информација, креирања и преношења садржаја коришћењем дигиталних технологија (Lankshear 14). За разлику од информатичке, дигитална писменост се односи на читање и разумевање дигитално написаних текстова и мултимедијалних садржаја, као и на стваралачки приступ коришћењу дигиталних медија. Она не подразумева само техничка и практична знања, већ смислену и функционалну употребу савремених технолошких средстава.

Иако је подстицање дигиталне писмености потребно укључити у све наставне предмете, кључна је улога наставе српског језика. Управо ту постоји највише простора да се нови облици писмености повежу са циљевима који су традиционално дефинисани у настави српског језика, а односе се на способност читања, разумевања прочитаног, 
тумачења текста и стваралачког изражавања. Зато у настави српског језика развој дигиталне писмености не може бити одвојен од осталих циљева предвиђених Наставним планом и програмом. На њега се не може утицати изоловано, новим и издвојеним задацима, већ се мора повезати са већ постојећим методичким поступцима који се традиционално користе. Пажљиво осмишљеним и добро организованим активностима уз употребу технологије настава српског језика може се осавременити, обогатити и допунити, а да се притом не изгуби квалитет који је заснован на провереним традиционалним принципима.

\section{Законски оквир}

У члану 4. Закона о основама система образовања и васпитања као један од циљева наводи се „развој способности проналажења, анализирања, примене и саопштавања информација, уз вешто и ефикасно коришћење информационо-комуникационих технологија“ (3). Документ Стандарди компетенција за професију наставника одређује да је кључна улога наставника да код ученика развија компетенције које их оспособљавају за живот и рад и пружају им основу за даље учење. У документу Оквир националног курикулума дигитална компетенција дефинисана је као једна од општих међупредметних компетенција. То значи да настава сваког предмета има задатак да да користи могућности које пружа ИКТ. „Један од основних начина да се то учини јесте да се разне врсте задатака, вежбања и активности у предметној настави осмисле тако да је за њихову реализацију потребно користити разноврсна ИКТ средства“" (24). Cтратегија развоја образовања у Србији до 2010. године предвиђа да се „користе предности информационо-комуникационих технологија и различитих облика учења у онлајн окружењу (електронске конференције, предметни блогови, дискусионе трибине, електронска тестирања итд.), а треба испитати и услове за коришћење неких видова наставе на даљину“ (43).

Међутим, дигитална писменост се не помиње у два документа која су кључни ресурс наставницима за планирање и организацију 
наставног процеса. Она није уврштена међу циљеве и задатке наставе српског језика у Наставним програмима за основну школу, а не помиње се ни у Образовним стандардима за крај основног образовања за наставни предмет Српски језик. Усаглашавање свих поменутих докумената препуштено је самим наставницима и зависи највише од њиховог ентузијазма и степена дигиталних компетенција. Самим тим постоји неуједначеност примене предложених решења у свакодневној наставној пракси (Џигурски и др. 41 - 52).

Разматрајући наведене документе, може се закључити да је осавремењавање наставе српског језика у складу са развојем дигиталних технологија препознато као важан циљ и предвиђено законским одредбама, али се ове одредбе још нису почеле доследно примењивати у пракси. Управо зато би искуство наставника који који их примењују могло бити од велике важности и дало смернице како да се дате смернице имплементирају у наставне планове и програме.

\section{Примери из праксе}

Удаљемрадубићенаведененекеодмогућностизаорганизовање наставе српског језика уз помоћ дигиталних технологија. Све описане активности организоване су са ученицима 6,7. и 8. разреда у току редовне наставе и ваннаставних активности. У неким случајевима примењен је принцип интердисциплинарности и успостављена корелација са другим наставним предметима, а посебно часовима информатике на којима су ученици овладавали употребом рачунара решавајући задатке и бавећи се темема постављеним на часовима српског језика.

\section{Домаћи задаци на Мудл платформи}

Употреба платформи за учење на даљину пружа могућност за примену принципа хибридне наставе: класична настава допуњена је повременим активностима организованим у дигиталној учи-

оници и домаћим задацима организованим помоћу система за 
учење на даљину - Мудл платформе (Спасојевић 12 -13). Оваквом организацијом рада знатно се може унапредити квалитет писаних задатака и интензивније развијати вештине писаног изражавања..

Према методичким принципима у настави српског језика сваки писани задатак или домаћи задатак требало би детаљно анализирати са свим ученицима, а након указивања на грешке ученици треба да приступе изради побољшане верзије (Николић 649 - 656). Такав начин рада није могуће квалитетно извести на традиционалан начин; за анализу задатака предвиђен је углавном један час, што није довољно да би се пажња посветила сваком раду. Израдом писаних задатака на онлајн платформи постиже се не само уштеда времена већ и индивидуализација, а пажња се може подједнако посветити сваком ученику и сваком задатку. Наставнику је олакшано прегледање ученичких радова и њихова компаративна анализа. Током израде задатака, ученицима се може омогућити подршка и помоћ наставника или осталих ученика путем форума и порука.Након што наставник прегледа задатке и исправи грешке, може захтевати од ученика израду побољшане верзије задатка. Ученицима је знатно лакше да испуне овај захтев користећи платформу него пишући побољшану верзију задатка у свеске, а наставнику је лакше да прати реализацију задатка и напредак ученика.

Анализа задатака треба да садржи и дискусију, процену задатака од стране других ученика и вршњачко оцењивање. Постављањем свих задатака на једно место, ученици имају увид у све остале задатке и у прилици су да их коментаришу и критички процењују. Мудл платформа пружа готове алате за организовање вршњачког оцењивања. Сваком ученику може се доделити одговарајући број радова које ће прочитати, анализирати и оценити. Такође, може се дефинисати више критеријума за процену радова и захтевати од ученика да напишу детаљно образложење своје оцене за сваки од критеријума. Овим се пажња посебно усмерава на развијање критичког мишљења, које се сматра једном од најзначајнијих компетенција ученика у 21. веку.

Задаци могу бити формулисани и у облику дискусија на форуму. Ако наставник осмисли теме које су инспиративне за ученике, ови задаци могу бити веома корисни и продуктивни. Њима се може оствари- 
ти велики број циљева наставе матерњег језика, као што су развијање критичког мишљења, вештине аргументовања сопствених ставова, неговање концизног, јасног и правилног изражавања, неговање културе дискусије уз уважавање туђег мишљења и др. Основна предност дискусија на форуму у односу на усмене дискусије на часу јесте у томе што ученици имају више времена за размишљање. Такође, писаним дискусијама ученици приступају са већом одговорношћу, а оне активирају и оне ученике који су усмено мање активни. Наравно, дискусије на форуму не могу заменити усмене дискусије на часу, али их могу допунити и обогатити. Њиховом употребом може се превазићи проблем недостатка времена, који постоји при обради многих наставних јединица. Превазилази се и проблем стидљивости код појединих ученика који су сигурнији при писаном него при усменом изражавању сопствених ставова.

Масовно коришћење савремених технологија поставља нове изазове и пред наставу правописа. Коришћење мобилних телефона довело је до неколико проблема: доминацију латиничног писма, употребу искључиво малих слова и одсуство дијакритичких знакова. Честе грешке у писменим задацима указују на преношење навика из неформалне комуникације путем смс порука. Посебно се ови проблеми уочавају када се од ученика захтева да доставе текст у дигиталном облику. Чешћим организовањем домаћих задатака путем интернета ученици стичу свест о томе да је и у онлајн окружењу потребно поштовати правописна правила и стичу навике да их доследно примењују. Одговорност се појачава ако наставник континуирано указује на грешке, инсистира на њиховом исправљању и уврсти то у критеријуме за оцењивање.

\section{Креирање дигиталних садржаја помоћу веб-алата}

Дигитална писменост подразумева не само коришћење, већ и креирање дигиталних садржаја. На интернету се могу пронаћи многобројни алати намењени креирању и дељењу разноврсних мултимедијалних садржаја: презентација, електронских књига, мапа 
ума, интерактивних постера, временских линија. Њима се могу представити прикази књижевних дела, сликовито систематизовати знања из појединих области, објединити занимљиви извори о делима и писцима, креирати подсетници или интерактивне вежбе за проверу знања. Ови алати су најчешће веома једноставни за коришћење, лако су доступни и ученици веома брзо овладавају њима.

Ученици радо приступају креирању мултимедијалних презентација које подразумевају обраду фотографија, звука, видеоснимака. Њихова заинтересованост може се искористити као мотивационо средство за достизање озбиљних образовних циљева у настави језика и књижевности. Задатак наставника је да испланира и осмисли такве задатке којима ће се ангажовати различити мисаони процеси и развијати разноврсне компетенције. Наставник, пре него што приступи примени ових алата у настави, треба добро да испланира начин рада имајући у виду циљеве које жели да постигне. Израда мултимедијалних презентација не треба за ученике да представља циљ, већ средство којим ће испољити своју креативност, применити стечена знања и представити своје виђење задате теме. Презентација, колико год визуелно била атрактивна, не сме се свести на пуко ређање слика и информација нити на визуелн-звучни спектакл.

Пре свега, мора се водити рачуна о одабиру и коришћењу информација. Ученике постепено треба оспособљавати да проналазе релевантне изворе информација, да их упоређују и критички процењују. У почетку наставник може да одабере одговарајуће ресурсе и учини их доступним ученицима, а касније да инсистира не само на навођењу коришћених извора, већ и на образложењу зашто су баш они одабрани. Од почетка треба водити рачуна да се коришћење ресурса не своди на копирање и преузимање готових садржаја. Ученике треба учити одговорном коришћењу технологије, уз поштовање ауторских права и спречавање плагијаризма. Ово није једноставан задатак, зато му треба приступити поступно и континуирано. Ако још од млађих разреда ученицима задају одабрани задаци, у складу са њиховим узрастом и способностима, ученици ће при крају основне школе бити способни за креирање оригиналних и квалитетних садржаја. 
Употреба веб-алата посебно се може искористити у додатној настави и ваннаставним активностима. Њихова употреба може дати нову димензију секцијама као што су литерарна и новинарска. Постоје бројни алати за креирање електронских часописа који се могу искористити за објављивање ученичких радова или израду школских часописа. Постављањем ученичких радова на интернет повећава се мотивација ученика за њихову израду, али и одговорност и озбиљност приступа јер ученици постају свесни да ће увид у њихове радове имати већи број људи.

\section{Блог - свеска доступна свима}

Развој дигиталних технологија довео је до експанзије блога и јачања његовог утицаја у друштву. Једноставност креирања блога омогућио је његово коришћење у настави. Велики број наставника користи блог како би комуницирао са ученицима и делио наставне материјале. Школе такође користе блог како би објављивале обавештења и извештаје о важним активностима.

Употреба блога у настави српског језика омогућава повезивање традиционалне наставне методологије са модерним приступима. Писањем блог чланака ученици развијају исте способности као и у традиционалној настави писаног изражавања, али их и обогаћују. Обликовањем визуелних елемената може се успоставити добра корелација са наставом ликовне културе, а развијање информатичке писмености се подразумева.

Блог се може користити на различите начине, као тематски, одељењски, разредни, лични. Може послужити као дневник читања, за објављивање радова насталих на секцијама. Може послужити за промоцију различитих школаских активности и представљати дневник свеукупног школског живота. Чланци се могу делити путем друштвених мрежа, што доприноси њиховој читаности. Наставник треба да пажљиво осмисли теме које су актуелне и ученицима занимљиве, а свакако треба и ученицима омогућити да сами бирају теме о којима желе да пишу. 


\section{Међународна сарадња између школа}

Развој технологије, између осталог, омогућио је једноставну комуникацију и сарадњу између особа које су просторно веома удаљене. Последњих година развили су се различити облици виртуелне сарадње између просторно удаљених школа, а те активности све више постају и обавезни елемент наставних планова и програма неких школа.

У свету постоје бројне платформе намењене комуникацији и сарадњи између ученика и наставника из различитих школа и земаља. Једна од најпознатијих је Етвининг, платформа која повезује више десетина хиљада школа из скоро свих европских земаља. Ова платформа нуди готове алате за комуникацију и сарадњу међу школама и за повезивање наставника који сарађују на заједнички осмишљеним пројектима. Ученици креирањем и разменом дигиталних садржаја обрађују разноврсне теме и у прилици су да директно комуницирају са својим вршњацима из других школа, путем форума или видеоконференција. Организацијом оваквих активности код ученика се развијају бројне компетенције неопходне за будући живот и рад: комуникацијске, сарадничке, језичке и дигиталне вештине. Такође се постиже и интердисциплинарност, која је један од императива савремене наставе.

Иако, у поређењу са осталим предметима, у настави српског језика постоји највише ограничења за интеграцију међународне сарадње у наставни програм, постојање све већег броја пројеката сведочи да се многим активностима остварују управо циљеви дефинисани програмом наставе српског језика.

Пример добре праксе може бити пројекат „We are Slavs“ који је повезао школе из неколико словенских земаља. Ученици су се, између осталог, бавили поређењем словенских језика и уочавањем сличности које сведоче о њиховом заједничком пореклу, што је допринело квалитетнијој реализацији наставних тема које се проучавају у 8. разреду, али и касније у средњој школи. Израдом презентација о словенским божанствима обновили су садржаје који се обрађују у 6. разреду, а израдом заједничког речника унапредили знања из лексикологије. 
Други пример је пројекат „Заједно растемо у пјесми и причи“, који је повезао неколико школа из Србије, Хрватске и Босне и Херцеговине. Ученици су сарађивали на матерњим језицима обрађујући књижевна дела која су заједничка наставним програмима свих земаља учесница пројекта.

Најзанимљивији део ових пројеката и њихов највећи изазов била је активност у којој су ученици у групама које су чинили чланови из различитих школа заједнички решавали одређене задатке. Да би решили задатке чланови група морали су да комуницирају путем интернета, да се договарају, истражују и обрађују податке преузете са интернета и креирају нове садржаје. Ови задаци су заиста били захтевни и били би тешки и за много искусније кориснике интернета него што су то ученици основних школа. Међутим, показало се да су им ученици већ дорасли, ако су правилно усмеравани од стране наставника. Те су активности на најбољи начин показале како се код ученика развијају компетенције потребне за живот и рад у будућности и колико је управо дигитална писменост важна за њихову будућност.

\section{Закључак}

Савремено образовање мора традиционалном значењу писмености да прикључи нове начине и облике изражавања и комуникације. Само тако се ученици могу успешно припремити за изазове које их очекују у њиховом будућем животу и будућим занимањима. Развијање дигиталне писмености не може бити изоловано. Као што је важно да се елементи основне писмености развијају у свим наставним предметима, тако је битно да се у наставу српског језика уврсти јачање нових облика писмености.

Примери показују да се савремена технологија може искористити за рад са ученицима већ од најранијег узраста. Бројни алати за дидитално и онлајн учење доступни су, бесплатни и једноставни за употребу. Уз њихову помоћ настава која је у највећој заснована на традиционалним принципима може се усмерити у модерне токове. Потребно је искористити заинтересованост ученика за нове 
технологије како би се нови облици интегрисали у традиционалне, а ученици имали максималну корист од такве наставе.

Важно је, такође, водити рачуна да средство не постане циљ. Коришћење дигиталних технологија неће наставу учинити квалитетнијом ако постане само себи сврха. Технологија нам може помоћи и олакшати рад, али уз јасно дефинисане циљеве и пажљиво осмишљене активности. Таквим приступом ћемо код ученика подстицати бројне нове вештине и компетенције, али без занемаривања основних поставки и примарних циљева наставе српског језика.

\section{Литература}

Закон о основама образовања и васпитања. Службени гласник РС, бр. 72/2009, 52/2011, 55/2013, 35/2015: 3

Јурић, Славица. Концепти нове писмености. 2013. Web. Доступно на: http:// obrazovneparadigme.pbworks.com (19.2.2017)

Lankshear, Colin and Michele Knobel. Digital Literacy and Digital Literacies. Digital Competance 1 - 2006. Dostupno na: http://everydayliteracies.net/files/digital_ kompetence_2006.pdf (20.2.2017)

Николић, Милија. Методика наставе српског језика и књижевности. Завод за уџбенике и наставна средства, Београд 1992.

Оквир националног курикулума - основи учења и наставе, радни нацрт: 24 Доступно на: http://www.osdositej.edu.rs/222.pdf (19.2.2017)

Попадић, Драган и Кузмановић Добринка. Млади у свету интернета. Министарство просвете, науке и технолошког развоја, 2016.

Cтратегија развоја образовања у Србији до 2010. године. Службени гласник РС, бр. 107/12: 43

Спасојевић, Олгица. „Унапређење наставе српског језика креирањем е-часова на Мудл платформи“. Информационо-комуникациона технологија у настави: зборник. Прир. Слободан Попов. Нови Сад, Центар за развој и примену науке, технологије и информатике, 2015.

Џигурски, Север и др. Истраживање о употреби информационо-комуникационих технологија у школама у Србији. Влада Републике Србије 2013. 


\section{Olgica Spasojevic \\ Primary school "Petar Lekovic" Pozega}

\section{THE ROLE OF SERBIAN LANGUAGE TEACHING IN THE DEVELOPMENT OF DIGITAL LITERACY}

\section{Summary}

Development of elementary literacy in the 21st century is inseparable from digital literacy. Althoug Curriculum does not insist in the development of digital literacy, in practice they are strongly connected.

This work shows how the different activities organized using technology achieve development of digital literacy, along with the realization of the Curriculum.

Practical examples show the possibilities offered by Moodle platform for organizing various activities in intention to achieve: improving the quality of written assignments, the use of peer to peer assessments, encouraging critical thinking, improving the teaching of certain content such as lexicography and spelling.

The use of various web tools provides students the opportunity for communication, cooperation and creation of digital and multimedia content. Students need to understand that durring the creation of digital content they should care for the linguistic and orthographic norms, responsible use of technology and copyrights.

Using a blog in teaching and extracurricular activities encourage the development of creativity, critical thinking and digital skills.

Digital literacy can be developed through Project-based Learning. Examples of international eTwinning projects show that it is possible to integrate international cooperation into Curriculum.

Key words: digital literacy, teaching, Serbian language 